\title{
THE EFFECT OF BUDGET PLANNING AND BUDGET EVALUATION ON SOCIAL SERVICES PERFORMANCE OF KARAWANG DISTRICT
}

\author{
Hari Sulistiyo \\ Universitas Singaperbangsa Karawang \\ Hari.sulistiyo@fe.unsika.ac.id \\ Feren Ayu Pratiwi \\ Universitas Singaperbangsa Karawang \\ 1610631030112@student.unsika.ac.id
}

\begin{abstract}
The Effect of Budget Plannng and Budget Evaluation On Social Service performance of karawang District.The purpose of this study was to determine the effect of Budget Planning and Budget Evaluation on the Performance of the Social Service in Karawang Regency. Sampling in this study using of 150 respondents. The data collection technique uses a survey method with a questionnaire tool. Data analysis was performed by validity test, reliability test, descriptive analysis and verification analysis with multiple linear regression. The results of this study show that simultaneously with statistical tests it shows that budget planning and budget evaluation have a significant effect on the performance of the Social Service of Karawang Regency. In addition, partially budget planning has a significant effect on the performance of the Social Service of Karawang Regency, budget evaluation has a significant effect on the performance of the Karawang Regency Social Service.
\end{abstract}

Keywords: Budget Planning, Budget Evaluation, Performance

Abstrak: Pengaruh Perencanaan Anggaran dan Evaluasi Anggaran Terhadap Kinerja Dinas Sosial Kabupaten Karawang.Tujuan penelitian ini adalah untuk mengetahui pengaruh Perencanaan Anggaran dan Evaluasi Anggaran terhadap Kinerja Dinas Sosial Kabupaten Karawang. Pengambilan sampel dalam penelitian ini menggunakan sampel sebanyak 150 responden. Teknik pengumpulan data menggunakan metode survei dengan alat angket. Analisis data dilakukan dengan uji validitas, uji reliabilitas, analisis deskriptif dan analisis verifikatif dengan regresi linier berganda. Pengolahan data menggunakan aplikasi software SPSS Versi 20. Hasil penelitian ini menunjukkan bahwa secara simultan dengan uji statistik menunjukkan bahwa perencanaan anggaran dan evaluasi anggaran berpengaruh signifikan terhadap kinerja Dinas Sosial Kabupaten Karawang. Selain itu, secara parsial perencanaan anggaran berpengaruh signifikan terhadap kinerja Dinas Sosial Kabupaten Karawang, evaluasi anggaran berpengaruh signifikan terhadap kinerja Dinas Sosial Kabupaten Karawang.

Kata Kunci: Perencanaan Anggaran, Evaluasi Anggaran, Kinerja

\section{INTRODUCTION}

Social problems in Indonesia are still a concern among the public. Social welfare that exists in each region is a concrete problem that needs to be addressed, one of which is in Karawang Regency. Social welfare problems that occur in Karawang Regency include the poor, people with disabilities, neglected children, neglected elderly people, street children, homeless people and beggars and others. The problem of social welfare will always continue to occur in the Karawang Regency area, therefore it requires good handling starting from the setting of social service targets through formulating policies and programs, implementing activities to the results of evaluation of activities. While the types and 
Number of PSKS (Potential and Sources of Social Welfare) in Karawang Regency are shown in table 1.

Table 1: Potential Sources of Social Welfare Resources (PSKS) Karawang Regency 2016-2019

\begin{tabular}{|c|c|c|c|c|c|}
\hline \multirow{2}{*}{\multicolumn{2}{|c|}{ N0 Total PSKS }} & \multicolumn{4}{|c|}{ Total Population } \\
\hline & & 2016 & 2017 & 2018 & 2019 \\
\hline 1 & $\begin{array}{l}\text { Professional } \\
\text { Social } \\
\text { Workers }\end{array}$ & 6 & 6 & 6 & 3 \\
\hline 2 & $\begin{array}{l}\text { Community } \\
\text { Social } \\
\text { Workers } \\
\text { (PSM) }\end{array}$ & 1.545 & 927 & 927 & 927 \\
\hline 3 & $\begin{array}{l}\text { Disaster } \\
\text { Preparedness } \\
\text { Youth } \\
\text { (TAGANA) }\end{array}$ & 45 & 45 & 45 & 37 \\
\hline 4 & $\begin{array}{l}\text { Child Welfare } \\
\text { Institution } \\
\text { (LKSA) }\end{array}$ & 52 & 47 & 36 & 41 \\
\hline 5 & $\begin{array}{l}\text { Youth } \\
\text { organization }\end{array}$ & 309 & 309 & 309 & 309 \\
\hline 6 & $\begin{array}{l}\text { Social } \\
\text { Welfare } \\
\text { Consultation } \\
\text { Institute } \\
\text { (LKKS) }\end{array}$ & 1 & 1 & 1 & 1 \\
\hline 7 & $\begin{array}{l}\text { Forum for } \\
\text { Community } \\
\text { Social } \\
\text { Welfare }\end{array}$ & 1 & 1 & 1 & 1 \\
\hline 8 & $\begin{array}{l}\text { Social } \\
\text { Extension }\end{array}$ & 2 & 2 & 2 & 3 \\
\hline 9 & $\begin{array}{l}\text { Community } \\
\text { Social } \\
\text { Welfare } \\
\text { Workers } \\
\text { (TKSM) }\end{array}$ & - & - & - & - \\
\hline 0 & $\begin{array}{l}\text { District Social } \\
\text { Welfare } \\
\text { Workers } \\
\text { (TKSK) }\end{array}$ & 30 & 30 & 30 & 30 \\
\hline 1 & $\begin{array}{l}\text { Business } \\
\text { world }\end{array}$ & - & - & - & - \\
\hline 2 & HR PKH & 228 & 228 & 288 & 280 \\
\hline 3 & $\begin{array}{l}\text { Social } \\
\text { organization } \\
\text { (Orsos) }\end{array}$ & 52 & 60 & 47 & 47 \\
\hline
\end{tabular}

Seeing the fact that there is, especially in relation to the conditions of social welfare implementation organized by the Karawang Regency Social Service in 2019, it is still not good, this is shown by the many complaints from the public about the low social welfare in Karawang Regency, both complaints through social media and community complaints. through musrenbang (Development Deliberations) in the District. The implementation of social welfare shows the performance of the Karawang Regency Social Service.

An agency's performance shows a fairly close relationship with an assessment of the success or failure of an agency. So that if the performance is good, then the level of success of the agency will be good, as according to Armstrong and Baron (1998: 150 ) in Wibowo (2010:70) suggesting that performance is about doing work and the results achieved from that work. According to Dwiyanto (2002) in Sudarmanto, (2015: 16-17) stated there are 5 indicators to measure organizational performance, namely

1. Productivity: by measuring the level of efficiency, effectiveness of services, and level of public service in order to achieve the expected results.

2. Service quality: by measuring people's satisfaction with the services provided. 


\section{Nominal: Barometer Riset Akuntansi dan Manajemen}

P-ISSN: 2303-2065 E-ISSN: 2502-5430

Volume 10 No 1 (2021)

3. Responsiveness: by measuring the ability of organizations to recognize community needs, develop service agendas and priorities, and develop public service programs in accordance with community needs and aspirations.

4. Responsibility: measuring the suitability of the implementation of public organization activities carried out with the principles of administration that are correct or in accordance with organizational policies.

5. Accountability: the extent to which the policies and activities of public organizations are subject to political officials elected by the people or measures that indicate the level of conformity of service delivery with the measures of external values or norms that exist in the community or those of the stakeholders.

To explore the phenomena that occurred in the Karawang Regency Social Service, the results of interviews with the Head of the Program and Reporting sub-division of the Karawang Regency Social Service showed that the number of PMKS (People with Social Welfare Problems) in Karawang Regency has increased from year to year, this is allegedly due to the performance of the Office Social in Karawang Regency in providing social services to PMKS is less than optimal. This is not only due to limited social welfare human resources (HR), the amount of available budget is not sufficient, facilities and infrastructure are not yet fully complete, as well as the diverse social values of society. The limited availability of formal legal issues regarding the implementation of social welfare also has an influence on the performance achievements of the implementation of social welfare.

According to Presidential Regulation Number 29 of 2014 concerning the Performance Accountability System of Government Agencies, each Regional Apparatus is required to report its performance, the performance of Regional Apparatus consists of Program Performance and Financial Performance. Program and Financial Performance Reports for each Regional Apparatus consist of annual performance reports and interim / quarterly performance reports.

The program performance and budget of the Karawang Regency Social Service in 2019 per quarter can be shown in Target and Achievement of Program Performance and Budget per Quarter Karawang Regency Social Service Period 2019 report on Social Service Karawang regency.

From the report, it can be seen that the preparation of the quarterly budget plan is not proportionally according to the performance targets that have been set per quarter, resulting in most of the quarterly budget 


\section{Nominal: Barometer Riset Akuntansi dan Manajemen}

P-ISSN: 2303-2065 E-ISSN: 2502-5430

Volume 10 No 1 (2021)

realization results not being achieved in accordance with the budget target per quarter, which should be the budget in quarter 1 . has been achieved or absorbed, but only absorbed in the 2nd, 3rd or 4th quarter. This also resulted in part of the performance target per quarter also not being achieved in accordance with the performance target per quarter.

Seeing the above problems, the realization of the Karawang Regency Social Service quarterly performance was not in accordance with what it should be. It can be concluded that while the budget planning is not good, besides that the budget evaluation carried out by the Karawang Regency Social Service is also not good. Budget evaluation also needs to be carried out to compare between the prepared budget and its implementation, so that from this comparison, irregularities can be seen. The deviations that occur will be used as a basis for measuring efficiency and assessing performance (Salbiah \& Rizky, 2012). Based on the background described above and to focus on the discussion in research, the authors took a study entitled "The Effect of Budget Planning and Budget Evaluation on Social Service Performance of Karawang District".

\section{LITERATURE REVIEW}

\section{Budget Planning}

Budget Planning process is one of the important steps in budget management, Since twelve months before the budget year began the budget planning process has begun BPKP, 2012 in the Zarinah, (2016).

According to the Directorate General of financial balance (2013: 127) planning as a reference for budgeting is basically the process of preparing revenue, expenditure and financing plans for a certain period of time.

According to Nasution in his book entitled Public Sector Accounting (proficient in regional financial planning and budgeting), 2019 that Planning can be interpreted as a process for determining appropriate future actions, through a sequence of choices, with the calculation of available resources. in the context of government development planning, the preparation is mainly guided by Law No. 25 of 2004 concerning the national development planning system. meanwhile, budgeting can be interpreted as a process for preparing a budget. APBD budget can be interpreted as the annual financial plan of the Regional Government which is discussed and agreed upon jointly by the regional government and the DPRD and determined by regional regulations.

\section{Budget Evaluation}


According to Mulyono and Yumari in their book entitled Budget Monitoring and Evaluation Strategy (2017) that Evaluation is the process of determining the value of an activity, policy or program. evaluation is an assessment that is carried out as objectively and systematically as possible on a planned, ongoing or completed intervention. matters that must be evaluated are projects, programs, policies, organizations, sectors, thematic and state aid. According to the shim in Yopi (2016) evaluation is a report that compares the actual budget achieved. According to Kenis in Adhimas (2016) evaluation is an action taken to trace the deposit of the department's budget and is used as a basis for department performance research. This will affect the behavior, attitude and performance of the manager. According to Tse (1979) in Adhimas (2016) explains that the evaluation basically has four objectives, namely:

1. Make sure that the real performance matches expected performance.

2. Makes it easy to compare individual performance with one another.

3. The performance evaluation system can trigger a danger signal, signaling problems that might occur.

4. To assess management policies in making decisions.

\section{Performance}

Armstrong and Baron (1998: 150) in Wibowo (2017: 70) suggest that performance is about doing work and the results achieved from the work. Performance is about what is done and how to do it. Performance is the result of work that has a strong relationship with strategic and organizational goals, customer satisfaction, and contributes to the economy.

The concept of performance is basically a change or a paradigm shift from the concept of productivity. Initially, people often use the term productivity to express a person's or an organization's ability to achieve goals for certain goals. According to Andersen (1995) in Sudarmanto (2015: 7), the new productivity paradigm is the actual performance paradigm which requires actual measurement of overall organizational performance, not only efficiency or physical dimensions, but also non-physical dimensions (intangible). Related to the concept of performance, Rummler and Branche (1995) in Sudarmanto (2015: 7-8) stated that there are 3 (three) levels of performance, namely:

1. Organizational Performance, is the achievement of results (outcomes) at the level or unit of organizational analysis. Performance at the organizational level is related to organizational goals, 


\section{Nominal: Barometer Riset Akuntansi dan Manajemen}

P-ISSN: 2303-2065 E-ISSN: 2502-5430

Volume 10 No 1 (2021)

organizational design, and organizational management.

2. Process Performance, is the performance of the process stages in producing products or services. Performance at this process level is influenced by process objectives, process design, and process management.

3. Individual / job performance, is the achievement or effectiveness at the level of employees or jobs. Performance at this level is influenced by job objectives, job design, and job management and individual characteristics.

According to Dwiyanto (2002) in Sudarmanto (2015: 16-17) stated there are 5 indicators to measure organizational performance, namely:

1. Productivity: by measuring the level of efficiency, effectiveness of services, and level of public service in order to achieve the expected results.

2. Service quality: by measuring people's satisfaction with the services provided.

3. Responsiveness: by measuring the ability of organizations to recognize community needs, develop service agendas and priorities, and develop public service programs in accordance with community needs and aspirations.

4. Responsibility: measuring the suitability of the implementation of public organization activities carried out with the principles of administration that are correct or in accordance with organizational policies.

5. Accountability: the extent to which the policies and activities of public organizations are subject to political officials elected by the people or measures that indicate the level of conformity of service delivery with the measures of external values or norms that exist in the community or those of the stakeholders.

Furthermore Dwiyanto (2012) in Sudarmanto (2015: 16-17) formulated 4 assessment indicators on organizational performance, namely:

1. Efficiency: concerns the consideration of the success of public service organizations to get profits, utilizing the factors of production as well as considerations derived from economic rationality.

2. Effectiveness: concerning technical rationality, values, mission, goals, organization and function of the development agent.

3. Fairness: concerns the distribution and allocation of services organized by public service organizations.

4. Responsiveness: responsiveness to the vital needs of the community, and can be accounted for transparently.

Based on the above framework, research paradigm can be arranged as follows: 


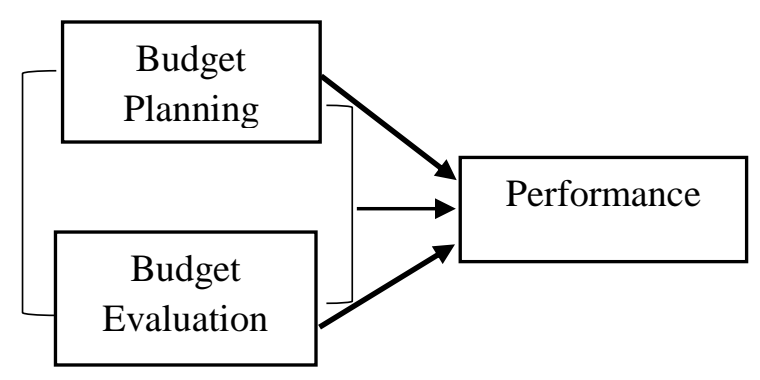

Figure 1: Research Paradigm

\section{Research Hypothesis}

Based on the theory and framework of thinking, the authors propose the following research hypotheses:

1. There is a effect of the Budget Planning and on Performance.

2. There is a effect of the Budget Evaluation on Performance.

3. There is a effect of Budget Planning and Budget Evaluation on Performance.

\section{RESEACH METHOD}

The research object is the Social Service of Karawang Regency. The method used is the expalanatory survey method, which is to analyze the effect that occurs between the budget planning variable (X 1), the budget evaluation variable (X 2), and performance (Y). The population in this study were 30 employees of the Karawang Regency Social Service and 1274 PSKS (Potential Sources of Social Welfare), consisting of 30 TKSK people, 927 PSM people, 280 PKH HR people, and 37 Tagana people, using the sampling technique. is the purposive sampling method. Purposive Sampling is a sampling technique with certain considerations. Based on the existing population, the sample size in this study is as many as 150 people who will be given a questionnaire, consisting of 30 employees of the Social Service of Karawang Regency, and for PSKS a sample is taken of 1 person each from 30 Districts consisting of out of 30 TKSK people, 30 PSM people, 30 PKH HR people, and 30 Tagana people. The sample collection from the PSKS has been determined by the researcher, namely the PSKS representative who often participates in program and budget meetings every month which are held at the Social Service of Karawang Regency, the PSKS data is taken from the attendance / attendance list at the meeting.

The data was collected by distributing questionnaires consisting of 3 variables, namely the Budget Planning Variable, the Budget Evaluation Variable and the Performance Variable with 8 question items for each variable. The scale used is the Likert scale with an answer range of 1 to $5(1=$ strongly disagree, 2 = disagree, 3 = disagree; $4=$ agree, $5=$ strongly agree)

Source: Processed based on sources for research purposes

The data analysis method used in this study consists of the Classical Assumption Test and Hypothesis Test with multiple linear regression analysis. 


\section{Data Validity Test}

The validity of a data relates to the degree of accuracy between the field data and the data reported by the researcher. To obtain valid data in quantitative methods, it is necessary to test the validity of the instrument. The validity of the instrument describes the level of the instrument that is able to measure what will be measured (Suharsimi, 2003:219). SPSS testing techniques are often used to test the validity of using Bivariate Pearson correlation (Pearson Moment Product) and Corrected Item-Total Correlation. The calculated $\mathrm{r}$ value is matched with the $r$ product moment table at a significant level of 5\%. If $r$ count is greater than $r$ table $5 \%$, then the item is valid.

From the results of the validity test of the Budget Planning variable (X 1), the Budget Evaluation variable (X 2), and the performance variable (Y) obtained 8 items of statement are all valid, because $r$ count is greater than $r$ table.

\section{Data Normality Test.}

The normality test is a test of whether or not the distribution of Budget Planning data is normal (X 1), Budget Evaluation (X 2), and Performance data $(Y)$. In this case it is done by using the Kolmogorov-Smirnov test using SPSs. With the criteria if the number of significance (sig) $<0.05$ then the data not normally distributed, and the significance number (sig) $>0.05$, the data is normally distributed.

The results of the normality test can be seen on Asympt.Sig. (2-tailed) shows a significance level greater than $\alpha=0.05$, namely $0.360>0.05$, which means that the data is normal distributed.

\section{Data Transformation}

Data transformation is an effort made with the main objective of changing the measurement scale of the original data into another form so that the data can fulfill the assumptions underlying the statistical analysis, so that the data is ready for analysis. Considering that the analysis used is path analysis, it is required that the measurement scale used is at least an interval scale. Because the data obtained from the research instrument is ordinal data, so that the relationship can be analyzed, the data must be transformed from ordinal to interval by using the method of successive interval (MSI).

\section{Design Analysis And Hypothesis Test Descriptive Analysis}

Scale ranges with a sample of 150 employees using the following formula:

$$
\begin{aligned}
& S R= \frac{n(m-1)}{m}=\frac{150(5-1)}{5}=120 \\
& \text { where }: \text { Scale Range } \\
& \text { SR }: \text { Number of Samples } \\
& \mathrm{n} \quad: \text { Number of Alternative } \\
& \mathrm{m} \quad \text { Answers (Score) }
\end{aligned}
$$

Lowest scale $=$ lowest score $\mathrm{x}$ number of samples $=1 \times 150=150$ 
Highest scale $=$ highest score $\mathrm{x}$ number of samples $=150 \times 5=750$

Table 2: Scale Range

\begin{tabular}{ccc}
\hline Score Scale & Scale Range & Criteria \\
\hline 1 & $150-269$ & Very Bad (STB) \\
2 & $270-389$ & Not Good (TB) \\
3 & $390-509$ & Not Good (KB) \\
4 & $510-629$ & Good (B) \\
5 & $630-750$ & Very Good (SB) \\
\hline
\end{tabular}

\section{VERIFICATION ANALYSIS}

\section{Multiple linear regression analysis}

Multiple linear regression aims to calculate the influence of two or more independent variables on one dependent variable and to predict the dependent variable using two or more independent variables. The multiple linear analysis formula is:

$\mathrm{Y}=\mathrm{a}+\beta 1 \mathrm{X} 1+\beta 2 \mathrm{X} 2+\mathrm{e}$

Information:

$\mathrm{Y}=$ Perfomance

$\mathrm{a}=$ Constant

$\beta 1=$ budget planning regression coefficient

$\beta 2=$ budget evaluation regression coefficient

$\mathrm{X} 1=$ Independent variable of budget planning

$\mathrm{X} 2$ = Independent variable of budget evaluation

$\mathrm{e}=$ error term is the estimator error rate in research

\section{RESULTS AND DISCUSSION}

\section{Validity and reliability test results}

This analysis is to determine the level of validity can be seen in the processed data.
Testing the research instrument both in terms of validity and reliability of 150 respondents. This instrument is declared valid if the $r_{\text {count }}>$ $r_{\text {tabel }}$ Sugiyono (2014: 121) and for reliability if the Cronbach's Alpha value is > 0.60 (Ghozali, 2009:46)

Test the validity and reliability of the Budget Planning variable (X1)

Based on the results of data analysis, the research results are obtained as in the table 3 . Table 3 explains that all statement items for the Budget Planning variable (X1) show valid results. This decision was taken because the value $r$ count $>r$ table, while the coefficient The alpha is 0.719 , thus it means that all statement items for the Budget Planning variable (X1) are reliable because Cronbach's Alpha> 0.60 .

Table 3: Results of Variable Validity and Reliability of Budget Planning Variables (X1)

\begin{tabular}{cccccc}
\hline $\begin{array}{c}\text { Item } \\
\text { No }\end{array}$ & $\begin{array}{c}\mathbf{r} \\
\text { count }\end{array}$ & r table & $\begin{array}{c}\text { Interpr } \\
\text { etation }\end{array}$ & Alpha & $\begin{array}{c}\text { Interp } \\
\text { retation }\end{array}$ \\
\hline 1 & 0,295 & & Valid & & \\
2 & 0,463 & & Valid & & \\
3 & 0,632 & & Valid & & \\
4 & 0,369 & $\geq 0,160$ & Valid & $0,719>$ & Reliable \\
5 & 0,629 & & Valid & 0,60 & \\
6 & 0,288 & & Valid & & \\
7 & 0,272 & & Valid & & \\
8 & 0,425 & Valid & & \\
\hline
\end{tabular}

Test the validity and reliability of the Budget Evaluation variable (X2)

Based on the results of data analysis, the research results are obtained as in the table 4 . The table 4 explains that all statement 
items are for the Budget Evaluation variable (X2) shows valid results, this decision was taken because the value $\mathrm{r}$ count $>\mathrm{r}$ tabel, while the alpha coefficient is 0.931 , thus it means that all statement items for the Budget Evaluation (X2) is reliable because Cronbach's Alpha> 0.60 .

Table 4: Results of Variable Validity and Reliability of Budget Evaluation Variables (X2)

\begin{tabular}{|c|c|c|c|c|c|}
\hline $\begin{array}{c}\text { Item } \\
\text { No }\end{array}$ & $\begin{array}{c}r \\
\text { count }\end{array}$ & $\begin{array}{c}r \\
\text { table }\end{array}$ & $\begin{array}{c}\text { Interp } \\
\text { Retation }\end{array}$ & Alpha & $\begin{array}{c}\text { Interp } \\
\text { retation }\end{array}$ \\
\hline 1 & 0,791 & & Valid & & \\
\hline 2 & 0,802 & & Valid & & \\
\hline 3 & 0,758 & & Valid & & \\
\hline 4 & 0,821 & $\geq 0,160$ & Valid & $0,931>$ & Reliable \\
\hline 5 & 0,722 & & Valid & 0,60 & \\
\hline 6 & 0,791 & & Valid & & \\
\hline 7 & 0,813 & & Valid & & \\
\hline 8 & 0,617 & & Valid & & \\
\hline
\end{tabular}

Test the validity and reliability of the Performance variable (Y)

Based on the results of data analysis, the research results are obtained as in the table 5 .

Table 5: Results of Variable Validity and Reliability Test Results of Performance Variables (Y)

\begin{tabular}{|c|c|c|c|c|}
\hline $\begin{array}{l}\text { Item } \\
\text { No }\end{array}$ & $\mathrm{r}$ coun $1 \mathrm{r}$ table & $\begin{array}{c}\text { Interpre } \\
\text { tation }\end{array}$ & Alpha & $\begin{array}{l}\text { Interp } \\
\text { retation }\end{array}$ \\
\hline 1 & 0,753 & Valid & \multirow{8}{*}{$\begin{array}{c}0,931> \\
0,60\end{array}$} & \multirow{8}{*}{ Reliable } \\
\hline 2 & 0,670 & Valid & & \\
\hline 3 & 0,863 & Valid & & \\
\hline 4 & $0,845 \geq 0,160$ & Valid & & \\
\hline 5 & 0,856 & Valid & & \\
\hline 6 & 0,872 & Valid & & \\
\hline 7 & 0,798 & Valid & & \\
\hline 8 & 0,451 & Valid & & \\
\hline
\end{tabular}

The table 5 explains that all statement items for the Performance variable (Y) show valid results. This decision was taken because the value of rcount $>$ rtable, while the alpha coefficient was 0.931 , thus it means that all statement items for the Performance variable (Y) are reliable because Cronbach's Alpha> 0, 60 .

\section{Normality test results}

The results of the normality test are seen in the Asymp.Sig. (2-tailed) value and the Kolmogorov-Smirnov $\mathrm{Z}$ value. If the resulting significance value is $>0.05$, the data distribution can be said to be normal. Conversely, if the resulting significance value $<0.05$, the data is not normally distributed.

Table 6: Normality Test

\begin{tabular}{llll}
\hline \multicolumn{1}{c}{ Variable } & Sig. & $\begin{array}{c}\text { Asymp. } \\
\text { Sig. } \\
\text { (2-tailed) }\end{array}$ & Description \\
\hline $\begin{array}{l}\text { Unstandardized } \\
\text { residual }\end{array}$ & 0,05 & 0,360 & Normal \\
\hline \multicolumn{1}{l}{ In the table } & 6, it & & \\
\hline
\end{tabular}

In the table 6 , it can be seen that the results of the normality test are seen in Asympt.Sig. (2-tailed) shows a significance level greater than $\alpha=0.05$, namely $0.360>$ 0.05 , which means that the data is NORMAL distributed.

\footnotetext{
Multiple Linear Regression Analysis test results

Multiple linear regression analysis is used to prove the extent of the influence between budget planning, budget evaluation and performance.
} 
Table 7: Multiple Regression Test Results and t Count

\begin{tabular}{|c|c|c|c|c|c|}
\hline \multirow[t]{2}{*}{ Model } & \multicolumn{3}{|c|}{ Coefficients } & \multirow[t]{2}{*}{$\mathbf{T}$} & \multirow[t]{2}{*}{ Sig. } \\
\hline & B & $\begin{array}{l}\text { Std. } \\
\text { Error }\end{array}$ & Beta & & \\
\hline (Constant) & 8,616 & 3,118 & & 2,763 & ,006 \\
\hline $\begin{array}{l}\text { Budget } \\
\text { 1Planing }\end{array}$ & ,373 & ,113 & ,254 & 3,296 & ,001 \\
\hline $\begin{array}{l}\text { BudgetEv } \\
\text { aluation }\end{array}$ & ,249 & ,076 & ,251 & 3,267 & ,001 \\
\hline
\end{tabular}

The analyzed the regression estimation model as follows: $\mathrm{Y}=8,616+$ $0,373 \mathrm{X} 1+0,249 \mathrm{X} 2+\mathrm{e} \ldots \ldots . .(1)$ from the above equation it can be explained that:

The regression coefficient of the budget planning variable (X1) of 0.373 identifies that if the budget planning increases, it will simultaneously increase the performance by 0.373 .

The regression coefficient of the Budget Evaluation variable (X2) of 0.249 identifies that if the Budget Evaluation increases, it will simultaneously increase the performance of 0.249 .

Table 8: Simultaneous F-Test Results

\begin{tabular}{lrrcrr}
\hline Model & $\begin{array}{c}\text { Sum of } \\
\text { Squares }\end{array}$ & Df & $\begin{array}{c}\text { Mean } \\
\text { Square }\end{array}$ & F & Sig. \\
\hline Regr & 617,230 & 2 & 308,615 & 0,892 &, 000 \\
Residual & 4165,184 & 147 & 28,335 & \\
Total & 4782,414 & 149 & & & \\
\hline
\end{tabular}

Based on the table above, it shows that in multiple regression testing the results of $F$ count is 10,892 with a significant value of 0,000 which is smaller than 0.05 , where the calculated $F$ value is greater than the $F$

table of $3.06(\mathrm{df} 1=3-1=2$ and $\mathrm{df} 2=150-3$ $=147$, it means that the variable budget planning and budget evaluation together have an effect on performance.

Table 9: The Result of Determination Coefficient Test $\left(\mathrm{R}^{2}\right)$

\begin{tabular}{lrrrr}
\hline Model & $\mathbf{R}$ & $\begin{array}{c}\mathbf{R} \\
\text { Square }\end{array}$ & $\begin{array}{c}\text { Adjusted } \\
\mathbf{R} \\
\text { Square }\end{array}$ & $\begin{array}{c}\text { Std. Error } \\
\text { of the } \\
\text { Estimate }\end{array}$ \\
\hline 1 &, $359^{\mathrm{a}}$ &, 129 &, 117 & 5,323024 \\
\hline
\end{tabular}

Based on the results of the coefficient of determination above, the value of $\mathrm{R} 2$ ( $\mathrm{R}$ square) from the regression model is used to determine how much the ability of the independent variable (independent) to explain the dependent variable (dependent). From the table above, it is known that the R2 value is 0.129 , this means that $12.9 \%$ shows that the performance is influenced by the budget planning and budget evaluation variables. Meanwhile, the remaining $87.1 \%$ is influenced by other variables not examined in this study.Overall, the verification analysis that researchers have done can be seen in the table 10 .

Based on the table 10 of the results of the verification analysis above, it can be explained that the Influence of $\mathrm{X} 1$ to $\mathrm{Y}$, the Influence of X2 to $\mathrm{Y}$ and the Influence of X1 and $\mathrm{X} 2$ to $\mathrm{Y}$ have a positive and significant effect. 
Table 10: Verification Analysis Results

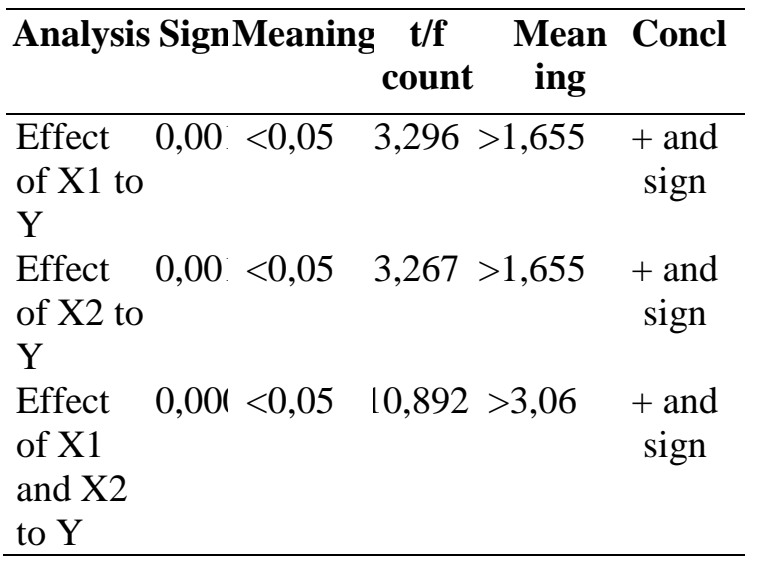

\section{Discussion}

Based on the results of the analysis of respondents' responses related to the phenomena that occur, the descriptive discussion can be described as follows:

Based on the descriptive analysis of the Budget Planning variable, it was found that the total score of the Budget Planning variable was 671 located on a scale range with very good criteria, meaning that the respondents had assumed that the initial budgeting planning at the Social Service of Karawang Regency was in accordance with the expected performance targets.

Judging from the frequency tabulation, the respondent's statement on the Budget Planning variable with the greatest percentage on the criterion strongly agrees, namely on the dimension of stakeholder involvement in the indicators of involvement with outsiders. Meanwhile, the greatest percentage of the criteria disagree is on the dimension of stakeholder involvement in the indicators of involvement between organizational parts.

Based on the descriptive analysis of the Budget Evaluation variable, it was found that the average total score of the Budget Evaluation variable was 647 located on a scale range with very good criteria, meaning that the respondents had assumed that the budget evaluation carried out at the Karawang district social service was very good.

Judging from the frequency tabulation, the respondent's statement on the Budget Evaluation variable with the greatest percentage on the criterion strongly agrees, namely the dimension of budget absorption on the indicator of comparison of performance realization with performance targat. While the greatest percentage is in the disagree criteria, namely in the dimension of budget absorption in the indicator of comparison of budget realization with the budget ceiling and comparison of performance realization with performance targets, the efficiency dimension in the program output efficiency indicator and the consistency dimension of budget absorption against planning on the deviation between realization indicators. budget with a withdrawal plan. 
Based on the descriptive analysis of the performance variables, it was found that the average total score of the performance variables was 638 , located on a scale range with very good criteria, meaning that the respondents had assumed that the performance achievement of the Karawang Regency Social Service was in accordance with the predetermined performance targets.

Judging from the frequency tabulation that the respondent's statement on the Performance variable with the greatest percentage on the criterion strongly agrees, namely on the dimensions of the productivity dimension on the indicator of the level of service efficiency. While the largest percentage with the criterion disagree less is on the dimension of responsiveness in the indicator of the organization's ability to recognize the needs of the community.

Based on the results of the research calculations that have been described previously, it can be presented about the verification discussion as follows:

\section{Effect of Budget Planning on Performance}

The effect of budget planning on the performance of the Karawang Regency Social Service based on the test obtained the sig value $(0.001)<\alpha(0.05)$ and $t_{\text {count }}(3.296)>$ $\mathrm{t}_{\text {table }}$ (1.655), then $\mathrm{H} 0$ is rejected. This test statistically proves that Budget Planning has a positive effect on performance, meaning that the Budget Planning variable significantly affects performance in the Social Service of Karawang Regency, this is due to the presence of good Budget Planning, the performance will be high. Based on the results of research and discussion, it can be concluded that the performance in this case the performance of the Social Service of Karawang Regency will increase if accompanied by good budget planning.

In addition, this study is in accordance with the results of previous research conducted by (2013) that the partial effect of budget planning on performance has a significant effect with the probability value of budget planning $=0.003<0.05$ which concludes that budget planning has a significant effect on performance and the results of previous research by Ahmari \& Amar (2014) states that budget planning has a positive and significant effect on performance.

\section{Effect of Budget Evaluation on Performance}

The effect of budget evaluation on performance in the Social Service of Karawang Regency based on hypothesis testing obtained $\operatorname{sig}(0.001)<\alpha(0.05)$ and $t_{\text {count }}(3.2667)>t_{\text {table }}(1.655)$, then $\mathrm{H} 0$ is rejected. This test statistically proves that 


\section{Nominal: Barometer Riset Akuntansi dan Manajemen}

P-ISSN: 2303-2065 E-ISSN: 2502-5430

Volume 10 No 1 (2021)

budget evaluation has a positive effect on performance, meaning that the budget evaluation variable significantly affects performance in the Social Service of Karawang Regency, this is due to the presence of a good budget evaluation, the higher the resulting performance. Based on the results of the research and the above discussion, it can be concluded that the budget evaluation carried out at the Karawang Regency Social Service has the potential to improve organizational performance in the area, where the local government assesses whether each SKPD activity is in accordance with the budget that has been set for the activity. so that local governments have benchmarks to improve their performance.

In addition, this study is in accordance with the results of previous research conducted by Salbiah and Rizky (2012) which states that budget evaluation has a significant positive effect on performance, and the results of previous research by (Jalaluddin \& Dafi, 2009) stated that budget evaluation has a positive and significant effect with a significance value. of 0.000 $<0.05$.

\section{Effect of Budget Planning and Budget Evaluation on Performance}

The effect of budget planning and budget evaluation simultaneously on performance at the Social Service of Karawang Regency based on the hypothesis test obtained the value of sig $(0.000)<\alpha(0.05)$ and $\mathrm{F}_{\text {count }}$ (10.892)> $F_{\text {table }}$ (3.06), then $H_{0}$ is rejected. This test statistically proves that budget planning and budget evaluation have a positive effect on performance, meaning that the variables of budget planning and budget evaluation significantly affect performance in the Social Service of Karawang Regency, this is due to the existence of good budget planning and budget evaluation, performance will be high, thus, if the budget planning and budget evaluation of the Social Service of Karawang Regency are done well, the performance will also increase.

In addition, this study is in accordance with the results of previous research by (Haslinda \& Jamaluddin, 2016) that the value of $F_{\text {table }}>F_{\text {count, }}$ namely: $23.810>3.18$ and the sig value, $0.000<\alpha$ 0.05 , it can be concluded that the variables of budget planning and evaluation budget together have an effect on performance.

\section{CONCLUSION AND SUGGESTIONS}

\section{Conclusion}

Research and discussion that has been done regarding the Effect of Budget Planning and Budget Evaluation on the Performance of the Social Service of Karawang Regency, the authors convey the following conclusions: 
1. Budget planning has an effect on the performance of the Social Service of Karawang Regency, meaning that the budget planning variable significantly affects the performance of the social service in Karawang Regency, this can be seen from the probability value of the budget planning variable which is 0.001 $<0.05$.

2. Budget Evaluation has an effect on the Performance of the Social Service in Karawang Regency, meaning that the budget evaluation variable significantly affects the performance of the Karawang Regency Social Service, this can be seen from the probability value of the Budget Evaluation variable, which is 0.001 $<0.05$.

3. Budget Planning and Budget Evaluation have an effect on the Performance of the Karawang Regency Social Service, meaning that the budget planning variables and budget evaluation variables significantly affect the performance of the Karawang district social services, this can be seen from the probability that the simultaneous test ( $\mathrm{F}$ test) is 0.000 smaller from 0.05 .

\section{Suggestions}

Based on the above conclusions, the suggestions that the author can submit are as follows:
1. Budget planning in the social office of Karawang Regency that is already good must be maintained, even more so. The low indicator, namely that it is not good at the involvement between parts of the organization, must be improved by means that every budget planning preparation always involves between parts of the Karawang regency social service organization. So that the budget planning is in accordance with the target of each section of the Karawang district social service.

2. Budget evaluation in the social service of Karawang regency that is already good must be maintained, even more so. Low indicators that are not good include:

a. The comparison of budget realization with the budget ceiling must be improved by compiling a budget ceiling according to the budget requirements in the current year.

b. Comparison of the realization of performance with performance targets must be improved by setting performance targets by taking into account the ability to achieve the achievement of performance targets.

c. program output efficiency must be improved by setting program output 
targets in line with the ability to achieve program output targets.

d. the deviation between budget realization and the fund withdrawal plan must be corrected by preparing performance targets, both monthly and quarterly targets, adjusted to the needs of withdrawing funds on a monthly or quarterly basis.

3. Performance in the Karawang regency social service which is already good must be maintained, even more so. The low indicator, which is not good enough in the organization's ability to recognize priority programs, must be improved by arranging priority programs by taking into account the social welfare problems that are happening in the community.

\section{REFERENCES}

Adhimas, Y. (2016). Pengaruh Karakteristik Penganggaran Terhadap. Padang: Universitas Negeri Padang.

Ahmari, A., \& Amar, S. (2014). Pengaruh Perencanaan, Pelaksanaan dan Pengendalian Anggaran Terhadap Kinerja Satuan Kerja Perangkat Daerah (SKPD) Kabupaten Kepulauan Mentawai. Jurnal Riset Manajemen Bisnis dan Publik,, 2(3).

Asmaranis, T. (2013). Pengaruh Perencanaan Anggaran, Pengelolaan Kas dan Pelaporan, Terhadap Kinerja Kepala SKPD (studi kasus pada Pemerintah Kota
Pematang Siantar). Medan: Tesis, FEB - Universitas Sumatera Utara.

Ghozali, I. (2009). Aplikasi Analisis Multivariate dengan Program SPSS. Semarang: UNDIP Press.

Haslinda, \& Jamaluddin. (2016). Pengaruh Perencanaan Anggaran dan Evaluasi Anggaran Terhadap Kinerja Organisasi Dengan Standar Biaya Sebagai Variabel Moderating Pada Pemerintah Daerah Kabupaten Wajo. Jurnal ilmiah Akuntansi Peradaban, II(1).

Jalaluddin, \& Dafi, B. (2009). Pengaruh Partisipasi Anggaran, Kejelasan Tujuan Anggaran, dan Evaluasi Anggaran Terhadap Kinerja Aparat Pemerintah Daerah (Studi Empiris Pada Satuan Kerja Perangkat daerah (SKPD) Kota Banda Aceh. Jurnal Telaah dan Riset Akuntansi, 2(1), 4453.

Mulyono, \& Yumari. (2017). Strategi monitoring dan evaluasi pelaksanaaan anggaran. Deepubllish, 1(1).

Nasution, D. (2019). kuntansi Sektor Publik (mahir dalam perencanaan dan penganggaran keuangan daerah). Ponorogo: Uwais Inspirasi Indonesia.

Peraturan Presiden Nomor 29 Tahun 2014 tentang Sistem Akuntabiitas Kinerja Instansi Pemerintah

Salbiah, \& Rizky, R. (2012). Pengaruh Evaluasi Anggaran Terhadap Kinerja Satuan Kerja Perangkat Daerah (SKPD) Pemerintah Provinsi 
Nominal: Barometer Riset Akuntansi dan Manajemen

P-ISSN: 2303-2065 E-ISSN: 2502-5430

Volume 10 No 1 (2021)

Sumatera Utara. Jurnal ekonom, 15(2).

Sudarmanto. (2015). Kinerja dan

Pengembangan Kompetensi SDM.

Cetakan ke-3. Yogyakarta: Pustaka

Pelajar.

Suharsimi, A. (2003). Prosedur Penelitian

Suatu pendekatan Praktik. Jakarta:

Rineka Cipta.

Wibowo. (2010). Manajemen Kinerja.

Cetakan ke-3. Jakarta: Rajawali Pers. 